\title{
Money supply and economic growth of Nepal: ARDL approach ${ }^{1}$
}

\author{
Keshar Bahadur Kunwar
}

\begin{abstract}
There are a number of theories illustrating the relationship between money supply and gross domestic product. Money supply can be defined as the total stock of money circulating in the economy. The circulating money involves the currency, printed notes, money in the deposit accounts, and in the form of other liquid assets. Valuation of money supply helps analysts and policy makers to frame the policy or to alter the existing policy of increasing or reducing the supply of money. The valuation is important as it ultimately affects the business cycle and thereby affecting the economy. This study sought to provide answers to the question, what are the effects of money supply on the gross domestic product in Nepal? The study undertook a causal research design using time series data from the period 1974/75 to 2017/18 to critically investigate the relationship between money supply and economic growth by establishing an empirical relationship that exists between them. The study employed the Augmented Diky fuller test and ARDL-VECM model. The results indicate the existence of a significant long-run relationship between money supply and economic growth as measured by GDP. LNBM is significant to LNGDP and LNGDP is also significant to $L N B M$ so there is bi-directional causality. There is unidirectional relationship existing between LNINF to LNGDP and LNINF to LNBM. ECT coefficient vale are negative and the p-value of above three approaches are also less than 5 percent which is desirable for the ARDL model.
\end{abstract}

Key words: ARDL; Augmented Dicky fuller; Broad money; Inflation; VECM

\footnotetext{
${ }^{1}$ Cite this article as: Kunwar, K.B. (2020). Contemporary Research: An Interdisciplinary Academic Journal, vol. 4 (1)

Keshar Bahadur Kunwar, Associate Professor, Tikapur Multiple Campus, Farwestern University, Nepal.

Email: keshar497@gmail.com

Article history: Received on July 4; Accepted on October 19; Published on October 30

Peer reviewed under the authority of CRAIAJ, academic journal of Ghodaghodi Multiple Campus, Kailali, Nepal, with ISSN 2717-4611 (Print) and ISSN 2717-462X (Online).

(C) 2020 CRAIAJ
}

Full text of this article can be downloaded from www.craiaj.com and www.nepjol.info 


\section{Introduction}

There is rising attention in money supply and its relationship to GDP. Over the past few years, modeling the relationship between money supply and income levels have been one of the main controversial issues of interest for economists, researchers and policy makers. Swamy (1994) noted that the public sector in the 1980s was becoming over-extended and increasingly suffered from economic mismanagement. Over the years, theories on the nexus between monetary policy and economic growth have flourished resulting in different strands of opinions among different schools of thought. This was predicated on the fact that high economic growth rate capable of translating into economic development required a proper mixed monetary policy variables, hence this has generated a lot of attention among various schools of thought ranging from Classical to neo-Classical, Keynesian to neo-Keynesian etc. In the present study, theoretical framework would be reviewed in two phases: impact of money supply on economic growth on the one hand and impact of inflation on economic growth on the other.

Theoretical propositions on the impact of money supply on economic growth are traceable to the Classical and Keynesian monetary theory, which is also known as Quantity theory of money. The Classical monetary theory is hinged on Irving Fisher equation of exchange or what he called value theory. Irving Fisher in his statement as cited by Jhingan (2005) postulated, "Other things remaining unchanged, as the quantity of money in circulation increases, the price level also increases in direct proportion and the value of money decreases and vice versa". This implies that the quantity of money is the main determinant of the price level or the value of money. Any change in the quantity of money produces an exactly proportionate change in the price level.

The Fisher equation of exchange states that the quantum of money multiplied by the velocity of money is equal to the price level multiplied by the amount of goods sold. It is often replicated as $\mathrm{MV}=\mathrm{PQ}, \mathrm{M}$ is defined as the quantity of money, $\mathrm{V}$ is the velocity of money (the number of times in a year that a currency goes around to generate a currency worth of income), $\mathrm{P}$ represents the price level and $\mathrm{Q}$ is the quantity of real goods sold (real output). On the contrary, the attack of Keynes on the classical quantity theorists brought about a reformulated quantity theory of money, which brought about a transition from monetary theory of prices to monetary theory

Full text of this article can be downloaded from www.craiaj.com and www.nepjol.info 
of output. Keynes integrated monetary theory with value theory and link theory of interest into monetary theory. In the Keynes statement as cited by Jhingan (2005), "it is through the theory of output that value theory and monetary theories are brought into just a position with each other".

Keynes disagrees with the older quantity theorists on their conclusion that there is a direct and proportional relationship between quantity of money and prices. He made it clear that, the effect of change in the quantity of money on prices is indirect and non-proportional and changes in the money supply affect only the absolute price level but exercise no impact on the relative price level. Keynes believes that so long as there is unemployment, output will change in the same proportion as the quantity of money and there will be no change in prices; and when there is full employment, prices will change in the same proportion as the quantity of money. Looking at the theories relating to Inflation Growth relationship, a number of theories and postulations were put forward by Classical, Keynesian, neo Keynesian, Monetarist, and Endogenous growth theorists, each with their respective contribution to the inflation-growth relationship.

Keynesian and Neo-Keynesian theory provided a more comprehensive model for linking Inflation to Growth under the aggregate supply-aggregate demand (ASAD) framework. The aggregate (AS-AD) framework postulated a positive relationship between inflation and growth where, as growth increased, so inflation does. According to this model, in the short-run, the (AS) curve is upward sloping rather than vertical, which is its critical feature. If the AS curve is vertical, changes on the demand side of the economy affect only prices. However, if it is upward sloping, changes in AD affect both price and output, (Dornbusch, et al., 1996). This holds that many factors drive the inflation rate and the level of output in the short-run. These include changes in: expectations, labour force, prices of other factors of production, fiscal and/or monetary policy.

\section{Literature review}

Aliason (2001) discloses three theoretical reasons often advanced for government money supply namely: first, if the government is unable to meet its expenditure commitments from domestically raised revenue, such as taxes, duties and externally sourced grants and borrowings, then it may resort to deficit financing where it borrows internally. 
Christensen (2004) employed a cross country survey of the role of money supply market in sub-Saharan African based on a new data set of 27 sub-Saharan African countries during the 20 years period (1980-2000), the study findings reveals that money supply markets in these countries are generally small, highly short term and often have a narrow investor base. Also in these countries "interest rate payment presents a significant burden to the budget, despite much smaller money supply than foreign indebtedness. Further still, it was revealed that the use of money supply is also found to have significant crowding out effect on private investment.

Oshadami (2006) carried out a study and found out that the growth of money supply has affected the growth of the economy negatively. This situation is premise on the fact that majority of the market participant are unwilling to hold longer maturity and as a result the government has been able to issue more short term debt instruments. This has affected the proper conduct of monetary policy and affected other macro-economic variables like inflation, which makes proper prediction in the economy difficult.

Abbas and Christensen (2007) in their recent study analyzed optimal money supply levels in the low income countries (including 40 sub-Saharan African Countries Kenya included) and emerging market between 1975 and 2004. They found out that moderate levels of marketable money supply as a percentage of GDP have significant positive effects on the gross domestic product. The study also provided evidence that the debt levels exceeding 35 percent of total bank deposits have negative impact on the gross domestic product. However, the relevance of this conclusion to Kenya doubtful since a lot of development has overtime been witnessed in the management of money supply. The country has witnessed an accelerated economic growth between 2005 and 2007 which was not captured in the study.

Looking at the impact of injection and withdrawal of money stock on economic growth in Nigeria, Taiwo, (2012) adopted Ordinary Least Square (OLS) of as estimation technique over a period of (1970-2008). The results revealed that monetary aggregate injection has positive effect on economic growth while withdrawal of money stock showed a negative impact on the GDP of Nigeria. Chinuba, Akhor, and Akwaden (2015) estimating a time series data covering a period 
of 1981-2008 with simple OLS on the Nigeria economy, the result supply that money supply exerts a considerable positive impact on economic growth.

\section{Specific objective}

The specific objectives are as follow:

- To assess the impact of money supply on GDP.

- To examine the relationship and causality among Gross Domestic Product (GDP), Broad Money (BM) and Inflation (INF).

\section{Research hypotheses}

$1 \mathrm{H}_{0}$ : Money supply has no significant contribution to GDP.

$2 \mathrm{H}_{1}$ : Money supply has significant contribution to GDP.

$3 \mathrm{H}_{0}$ : There is no relationship among the variables.

$4 \mathrm{H}_{1}$ : There is relationship among the variables.

$5 \mathrm{H}_{0}$ : There is no causality among the variables.

$6 \mathrm{H}_{1}$ : There is causality among the variables.

Significance of the study

This study focused on what policies can be formulated, what regulatory acts are needed and necessity of amendments regarding the rules and regulation to develop it and make the market perfect functioning. The standard is one of the elements to money market development. Financial statement should maintain accordingly which fulfill the requirement of related parties needed information. The study will provide relevant information for government organs. The researcher insights the study would be useful to formulate appropriate policy to all stakeholders. Furthermore, the study will be used as a reference for other researchers for further study in the topic.

\section{Limitation of the study}

There are some limitations of the study. Lack of time, limited budget, and updated information are the major limitations of the study. Apart from this some more limitation are presented below:

- The study centers on achieving the broad objective which is to evaluate the impact of money supply for the development of Nepalese economy. This study only covers the time period of forty-four years from 1974/75 to 2017/18 the rational for choosing this period is mainly for simplicity of analysis. Some selected variables do not have data of covering period. 
- This study will only use secondary data from the different sources so that validity and reliability may depend on the goodness of these data.

- This study will be examined the impact of money supply on GDP. It also includes broad money (BM) and Inflation (INF) explanatory variables at current price.

- It is not a complete study of money market of Nepal.

\section{Research methodology}

\section{The research design}

This study combines form of both analytical and descriptive research. It has used both the qualitative and quantitative techniques depending on the nature and source of data and information. This study applied some tools such as econometric models, graphs, tables and statistical tools.

\section{Nature and sources of data}

The basic objectives of the study analyze the impact of money supply on economic growth of Nepalese economy. In order to seek the information regarding this study the relevant materials review and gather the necessary information from the various secondary sources. Time series data covering period of forty-four years from 1974/75 to $2017 / 18$ has been used to assess the impact of money supply on GDP. The secondary data has been taken from Ministry of Finance (MOF), Nepal Rastra Bank (NRB) and various web pages including google.com, libraries as per need.

\section{Data collection tools and procedures}

The study has employed specific techniques of data collection and analysis methods in a way that seems pertinent to the study. As a result, it has used specific tool; review the existing data that enable to capture information pertinent to the study objectives. The study has employed a document reviewing method.

\section{Techniques of Data Analysis}

The information has been collected from the secondary sources processed to analyze regression. To address the objectives of the research and to analyze the data, descriptive statistics, simple and multiple regressions has been employed. The time series information (annual data has been used for statistical computations of the

contribution and hence, used for testing the hypotheses. Statistical computation has been employed to explore the inherent relationships among the variables. This study 
tests some reliable models like Augmented- Dickey Fuller unit root test and ARDL model which give reliability and validity of the model.

\section{Autoregressive distributed lag (ARDL)}

Economic analysis suggests that there is a long run relationship between variables under consideration as stipulated by theory. This means that the long run relationship properties are intact. In other words, the means and variances are constant and not depending on time. However, most empirical researches have shown that the constancy of the means and variances are not satisfied in analyzing time series variables. In the event of resolving this problem most co-integration techniques are wrongly applied, estimated, and interpreted. One of these techniques is the Autoregressive Distributed Lag (ARDL) co-integration technique or bound cointegration technique. Hence, this study reviews the issues surrounding the way cointegration techniques are applied, estimated and interpreted within the context of ARDL co-integration framework. The study shows that the adoption of the ARDL cointegration technique does not require pretests for unit roots unlike other techniques. Consequently, ARDL co-integration technique is preferable when dealing with variables that are integrated of different order, $\mathrm{I}(0), \mathrm{I}(1)$ or combination of both and, robust when there is a single long run relationship between the underlying variables in a small sample size.

The long run relationship of the underlying variables is detected through the F-statistic (Wald test). In this approach, long run relationship of the series is said to be established when the $\mathrm{F}$ statistic exceeds the critical value band. The major advantage of this approach lies in its identification of the co-integrating vectors where there are multiple co-integrating vectors. However, this technique will crash in the presence of integrated stochastic trend of I(2). To forestall effort in futility, it may be advisable to test for unit roots, though not as a necessary condition. Based on forecast and policy stance, there is need to explore the necessary conditions that give rise to ARDL co-integration technique in order to avoid its wrongful application, estimation, and interpretation. If the conditions are not followed, it may lead to model misspecification and inconsistent and unrealistic estimates with its implication on forecast and policy. 
The model specification and data measurement ARDL- VECM and casual inference model

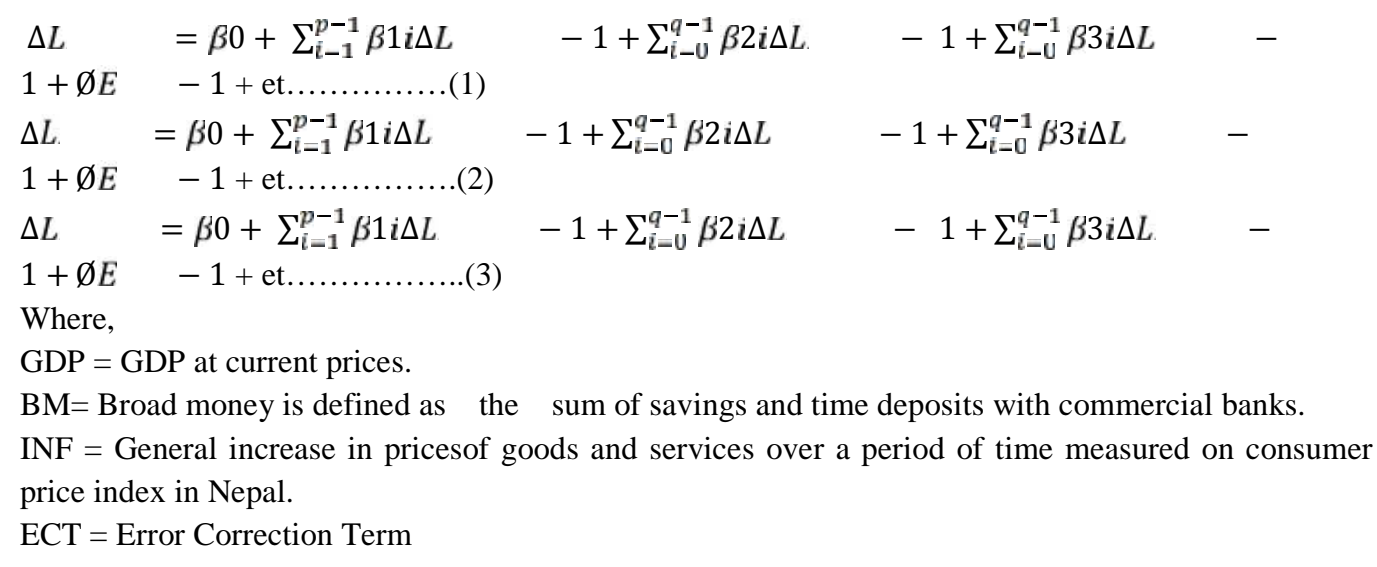
$\beta_{0}, \beta_{1}, \beta_{2}$ and $\beta_{3}$ are model parameters and et is the stochastic error term. The 'priori' expectation is that the model parameter is expected to be positively signed. The implication is the real context as growth has been expected even when BM and INF have been collected.

Natural logarithm has been used to make the data under study to be normal and linear. This is because natural log is one of the transformations methods that make the data normal if they are not normal with their actual numbers. It also gives elasticity.

\section{Data analysis and result}

\section{Empirical results}

Augmented Dickey Fuller (ADF) test has revealed that LNGDP and LNBM are nonstationary in level but when the variables are converted into first difference becomes stationary and the LNINF is stationary in level so this is mixed type in this case we can run ARDL model.

Table no 1.1: Augmented Dickey Fuller test

\begin{tabular}{|l|l|l|l|l|}
\hline Variables & $\begin{array}{l}\text { Level } \\
\text { constant }\end{array}$ & $\begin{array}{l}\text { Level constant and } \\
\text { trend }\end{array}$ & $\begin{array}{l}\text { First difference } \\
\text { constant }\end{array}$ & $\begin{array}{l}\text { First difference } \\
\text { constant and trend }\end{array}$ \\
\hline LNGDP & $\begin{array}{l}0.017543 \\
(09550)\end{array}$ & $\begin{array}{l}-1.860205 \\
(0.6575)\end{array}$ & $\begin{array}{l}-6.572602 \\
(0.0000)\end{array}$ & $\begin{array}{l}-6.487835 \\
(0.0000)\end{array}$ \\
\hline LNBM & -0.619807 & -2.187356 & -4.563283 & -4.543484 \\
& $(0.8552)$ & $(0.4840)$ & $(0.0007)$ & $(0.0040)$ \\
\hline LNINF & -4.465338 & -4.828814 & -10.13064 & -10.00741 \\
\hline
\end{tabular}

Full text of this article can be downloaded from www.craiaj.com and www.nepjol.info 


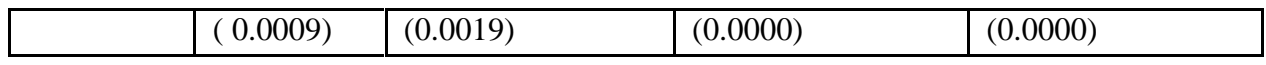

Source: Based on author's calculation

In above three models after running the ARDL the value of $F$ statistics and $T$ statistics are above the I(1) so the null hypothesis of no co-integration is rejected meaning there is co-integration and desirable to run long run error correction form. After running the long run error correction form following result appeared:

Table no 1.2: ARDL summarization

\begin{tabular}{|l|l|l|l|}
\hline Dependent variables & $\begin{array}{l}\text { Repressor's } \\
\text { statistics }\end{array}$ & ECT t-statistics & Pairwise Grager Test \\
\hline LNGDP & $\begin{array}{l}\text { LNBM- } \\
\text { Significant }\end{array}$ & Significant & $\begin{array}{l}\text { LNINF } \\
\text { LNINF _NBM } \\
\text { LNBM LNGP }\end{array}$ \\
\hline LNBM & $\begin{array}{l}\text { LNGDP- } \\
\text { Significant }\end{array}$ & Significant & \\
\hline LNINF & Insignificant & Significant & \\
\hline
\end{tabular}

Source: Based on author's calculation

LNBM is significant to LNGDP and LNGDP is also significant to LNBM so there is bi-directional causality. There is unidirectional relationship existing between LNINF to LNGDP and LNINF to LNBM. ECT coefficient vale are negative and the p-value of above three approaches are also less than 5 percent which is desirable for the ARDL model. (See in Appendix)

Table 1.3: Summary results of serial correlation, hetero-skedasticity, $\mathrm{ARCH}$ and normal distribution

\begin{tabular}{|l|l|l|}
\hline Particulars & $\begin{array}{l}\text { Obs* } \\
\text { R-squared }\end{array}$ & P-Value \\
\hline Breusch-Godfrey Serial Correlation LM Test: & 0.832499 & 0.6595 \\
\hline Heteroskedasticity Test: Arch & 0.108772 & 0.7541 \\
\hline Histogram Normality test & -- & 0.202612 \\
\hline
\end{tabular}

Source: Based on author's calculation

Here we choose Obs*R-squared and the corresponding $\mathrm{P}$-value which is greater than 5 percent in above three cases so here we cannot reject null hypothesis. The null hypothesis is not serially correlated, residuals are homoscedasticity, residuals are normally distributed which is desirable for the ARDL Model. So in conclusion this ARDL model is accepted. (See in Appendix)

\section{CUSUM test}

Full text of this article can be downloaded from www.craiaj.com and www.nepjol.info 
The green line is in between the two red lines so this model is desirable

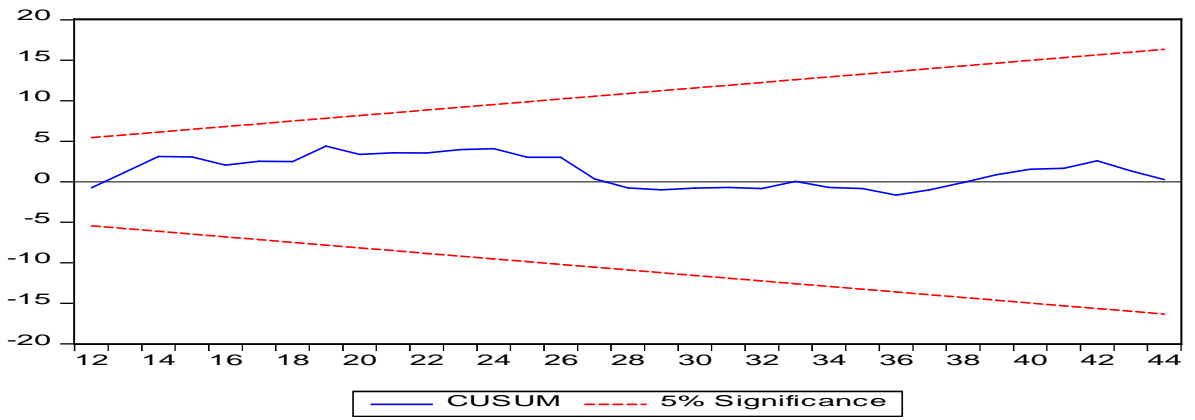

\section{Conclusion}

In conclusion, there is bi-direction causality existing between the broad money and gross domestic production. Inflation also causes to broad money and gross domestic production.

\section{Reference}

Abass S.M and Christensen J. E, (2007). The role of money supply markets in economic growth: An empirical investigation for low income countries and emerging markets. International Monetary Fund.

Allison, J (2001). Key issues for analyzing money supply sustainability. Debt Relief International publication 5.ISBN:1-903971-07-1.

Christensen, J. (2004). Money supply market in sub Saharan Africa. IMF working paper WP/0646

Chinwuba, O., Akhor, S. O., \& Akwaden, S. T. (2015). Monetary policy innovations and growth rate of output in Nigeria. International Journal of Economics and Business Management, 1(4), pp. 1-15.

Dornbusch, R., Fisher, S. and Kearny, C. (1996). Macroeconomics theory. The McGraw-Hill Companies, Inc., Sydney.

Dickey. D. A and W. A. Fuller (1979). Distribution of estimators of autoregressive time series with a unit root. Journal of the American Statistical Association, 74.

Engle, R. and Granger, C. W.J. (1987). Cointegration and error correction:

Representation, estimation and testing. Econometrica, 35, pp. 251-276.

Engle, R. and Granger, C. W.J. (1991). Long run economic relations: Readings in cointegration. Oxford: Oxford University Press.

Full text of this article can be downloaded from www.craiaj.com and www.nepjol.info 
Gujarati, D.N.,Porter, D.C., Gunasekar, S. ( 2012). Basic econometrics Fifth Edition, McGraw Hill Education (India) Pvt.Ltd, New Delhi, pp. 427-31.

Granger, C. W.J. (1969). Investigating causal relations by econometrics. Journal of Econometrics 2(2), pp. 111-120.

Swamy G. (1994). Kenya structural adjustment in the 1980s, World Bank Policy Research Working Paper 1238.Washington D.C.

Taiwo, M. (2012). Impact of injection and withdrawal of money stock on economic growth in Nigeria. European Journal of Business and Management Sciences, 4(2), pp. 33-42.

Jhingan, M. L. (2005). Macroeconomic theory (5th ed.). Vrinda Publications (P) Ltd. New Delhi, India. 
Appendix: ARDL Result

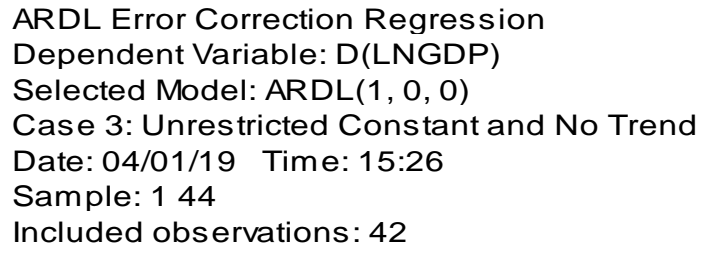

\begin{tabular}{|c|c|c|c|c|}
\hline \multicolumn{5}{|c|}{$\begin{array}{c}\text { ECM Regression } \\
\text { Case 3: Unrestricted Constant and No Trend }\end{array}$} \\
\hline Variable & Coefficient & Std. Error & t-Statistic & Prob. \\
\hline $\begin{array}{c}\mathrm{C} \\
\text { CointEq }(-1)^{*}\end{array}$ & $\begin{array}{r}1.077685 \\
-0.342568 \\
\end{array}$ & $\begin{array}{l}0.212342 \\
0.076220\end{array}$ & $\begin{array}{r}5.075231 \\
-4.494484 \\
\end{array}$ & $\begin{array}{l}0.0000 \\
0.0001\end{array}$ \\
\hline $\begin{array}{l}\text { R-squared } \\
\text { Adjusted R-squared } \\
\text { S.E. of regression } \\
\text { Sum squared resid } \\
\text { Log likelihood } \\
\text { F-statistic } \\
\text { Prob(F-statistic) }\end{array}$ & $\begin{array}{l}0.335552 \\
0.318941 \\
0.050106 \\
0.100423 \\
67.16124 \\
20.20039 \\
0.000058\end{array}$ & \multicolumn{2}{|c|}{$\begin{array}{l}\text { Mean dependent var } \\
\text { S.D. dependent var } \\
\text { Akaike info criterion } \\
\text { Schwarz criterion } \\
\text { Hannan-Quinn criter. } \\
\text { Durbin-Watson stat }\end{array}$} & $\begin{array}{r}0.123950 \\
0.060715 \\
-3.102916 \\
-3.020170 \\
-3.072587 \\
1.968519\end{array}$ \\
\hline
\end{tabular}

* $\mathrm{p}$-value incompatible with t-Bounds distribution.

F-Bounds Test Null Hypothesis: No levels relationship

\begin{tabular}{lcrrr}
\hline \hline Test Statistic & Value & Signif. & $\mathrm{I}(0)$ & $\mathrm{I}(1)$ \\
\hline \hline F-statistic & & & & \\
$\mathrm{k}$ & 6.396790 & $10 \%$ & 3.17 & 4.14 \\
& 2 & $5 \%$ & 3.79 & 4.85 \\
& & $2.5 \%$ & 4.41 & 5.52 \\
\hline \hline
\end{tabular}

t-Bounds Test

Null Hypothesis: No levels relationship

\begin{tabular}{lcrrr}
\hline \hline Test Statistic & Value & Signif. & $\mathrm{I}(0)$ & $\mathrm{I}(1)$ \\
\hline \hline \multirow{2}{*}{ t-statistic } & \multirow{2}{*}{-4.494484} & $10 \%$ & -2.57 & -3.21 \\
& & $5 \%$ & -2.86 & -3.53 \\
& & $2.5 \%$ & -3.13 & -3.8 \\
& & $1 \%$ & -3.43 & -4.1 \\
\hline \hline
\end{tabular}

Full text of this article can be downloaded from www.craiaj.com and www.nepjol.info 
Contemporary Research: An Interdisciplinary Academic Journal, 2020, vol. 4 (1): 76-94

ARDL Long Run Form and Bounds Test

Dependent Variable: D(LNGDP)

Selected Model: ARDL(1, O, O)

Case 3: Unrestricted Constant and No Trend

Date: 04/01/19 Time: 15:20

Sample: 144

Included observations: 42

Conditional Error Correction Regression

\begin{tabular}{crrrr}
\hline \hline Variable & Coefficient & Std. Error & t-Statistic & Prob. \\
\hline \hline C & 1.077685 & 0.299853 & 3.594046 & 0.0009 \\
LNGDP(-1 $^{*}$ & -0.342568 & 0.097109 & -3.527645 & 0.0011 \\
LNBM $^{* *}$ & 0.260373 & 0.073774 & 3.529360 & 0.0011 \\
LNINF $^{* *}$ & 0.031998 & 0.015842 & 2.019768 & 0.0505 \\
\hline \hline
\end{tabular}

* p-value incompatible with t-Bounds distribution.

** Variable interpreted as $Z=Z(-1)+D(Z)$.

\begin{tabular}{|c|c|c|c|c|}
\hline \multicolumn{5}{|c|}{$\begin{array}{c}\text { Levels Equation } \\
\text { Case 3: Unrestricted Constant and No Trend } \\
\end{array}$} \\
\hline Variable & Coefficient & Std. Error & t-Statistic & Prob. \\
\hline $\begin{array}{l}\text { LNBM } \\
\text { LNINF }\end{array}$ & $\begin{array}{l}0.760064 \\
0.093406\end{array}$ & $\begin{array}{l}0.011743 \\
0.056566\end{array}$ & $\begin{array}{l}64.72246 \\
1.651285\end{array}$ & $\begin{array}{l}0.0000 \\
0.1069\end{array}$ \\
\hline \multicolumn{5}{|c|}{$E C=$ LNGDP $-(0.7601 *$ LNBM $+0.0934 *$ LNINF $)$} \\
\hline F-Bounds Test & \multicolumn{4}{|c|}{ Null Hypothesis: No levels relationship } \\
\hline Test Statistic & Value & Signif. & $\mathrm{I}(\mathrm{O})$ & $\mathrm{I}(1)$ \\
\hline $\begin{array}{l}\text { F-statistic } \\
\text { K }\end{array}$ & $\begin{array}{l}6.396790 \\
2\end{array}$ & $\begin{array}{r}10 \% \\
5 \% \\
2.5 \% \\
1 \%\end{array}$ & $\begin{array}{r}\text { mptotic: } \mathrm{n}= \\
3.17 \\
3.79 \\
4.41 \\
5.15\end{array}$ & $\begin{array}{l}4.14 \\
4.85 \\
5.52 \\
6.36\end{array}$ \\
\hline Actual Sample Size & 42 & $\begin{array}{r}10 \% \\
5 \% \\
1 \%\end{array}$ & $\begin{array}{r}\text { ite Sample: } \\
3.33 \\
4.083 \\
5.92\end{array}$ & $\begin{array}{l}45 \\
4.347 \\
5.207 \\
7.197\end{array}$ \\
\hline & & $\begin{array}{r}10 \% \\
5 \% \\
1 \%\end{array}$ & $\begin{array}{r}\text { ite Sample: } \\
3.373 \\
4.133 \\
5.893 \\
\end{array}$ & $\begin{array}{r}40 \\
4.377 \\
5.26 \\
7.337 \\
\end{array}$ \\
\hline t-Bounds Test & \multicolumn{4}{|c|}{ Null Hypothesis: No levels relationship } \\
\hline Test Statistic & Value & Signif. & $\mathrm{I}(\mathrm{O})$ & $\mathrm{I}(1)$ \\
\hline t-statistic & -3.527645 & $\begin{array}{r}10 \% \\
5 \% \\
2.5 \% \\
1 \%\end{array}$ & $\begin{array}{l}-2.57 \\
-2.86 \\
-3.13 \\
-3.43\end{array}$ & $\begin{array}{r}-3.21 \\
-3.53 \\
-3.8 \\
-4.1\end{array}$ \\
\hline
\end{tabular}

Full text of this article can be downloaded from www.craiaj.com and www.nepjol.info 
ARDL Long Run Form and Bounds Test

Dependent Variable: D(LNBM)

Selected Model: ARDL $(1,0,1)$

Case 3: Unrestricted Constant and No Trend

Date: 04/01/19 Time: 15:32

Sample: 144

Included observations: 41

\begin{tabular}{crrrr}
\hline \multicolumn{5}{c}{ Conditional Error Correction Regression } \\
\hline Variable & Coefficient & Std. Error & t-Statistic & Prob. \\
\hline \hline C & -0.252025 & 0.251463 & -1.002238 & 0.3229 \\
LNBM(-1)* & -0.064565 & 0.060560 & -1.066138 & 0.2935 \\
LNGDP ** & 0.087170 & 0.079559 & 1.095654 & 0.2805 \\
LNINF(-1) & 0.060176 & 0.015261 & 3.943147 & 0.0004 \\
D(LNINF) & 0.036154 & 0.013873 & 2.606062 & 0.0132 \\
\hline \hline
\end{tabular}

* $\mathrm{p}$-value incompatible with t-Bounds distribution.

** Variable interpreted as $Z=Z(-1)+D(Z)$

\begin{tabular}{ccccc}
\hline \hline \multicolumn{5}{c}{$\begin{array}{c}\text { Levels Equation } \\
\text { Case 3: Unrestricted Constant and No Trend }\end{array}$} \\
\hline \hline Variable & Coefficient & Std. Error & t-Statistic & Prob. \\
\hline \hline LNGDP & 1.350100 & 0.072867 & 18.52838 & 0.0000 \\
LNINF & 0.932022 & 0.976623 & 0.954331 & 0.3463 \\
\hline \hline EC $=$ LNBM $-\left(1.3501^{*}\right.$ LNGDP $+0.9320 *$ LNINF $)$ & & \\
\hline \hline
\end{tabular}

F-Bounds Test

Null Hypothesis: No levels relations hip

\begin{tabular}{lcrrr}
\hline Test Statistic & Value & Signif. & $\mathrm{I}(0)$ & $\mathrm{I}(1)$ \\
\hline \hline & & & Asymptotic: $\mathrm{n}=1000$ & \\
F-statistic & 7.409564 & $10 \%$ & 3.17 & 4.14 \\
k & 2 & $5 \%$ & 3.79 & 4.85 \\
& & $2.5 \%$ & 4.41 & 5.52 \\
& & $1 \%$ & 5.15 & 6.36
\end{tabular}

Actual Sample Size

41

Finite Sample: $\mathrm{n}=45$

$\begin{array}{rrr}10 \% & 3.33 & 4.347 \\ 5 \% & 4.083 & 5.207 \\ 1 \% & 5.92 & 7.197\end{array}$

Finite Sample: $\mathrm{n}=40$

\begin{tabular}{rrr}
$10 \%$ & 3.373 & 4.377 \\
$5 \%$ & 4.133 & 5.26 \\
$1 \%$ & 5.893 & 7.337 \\
\hline
\end{tabular}

t-Bounds Test

Null Hypothesis: No levels relationship

\begin{tabular}{lcrrr}
\hline \hline Test Statistic & Value & Signif. & $\mathrm{I}(0)$ & $\mathrm{I}(1)$ \\
\hline \hline \multirow{2}{*}{ t-statistic } & \multirow{2}{*}{-1.066138} & $10 \%$ & -2.57 & -3.21 \\
& & $5 \%$ & -2.86 & -3.53 \\
& & $2.5 \%$ & -3.13 & -3.8 \\
& $1 \%$ & -3.43 & -4.1 \\
\hline \hline
\end{tabular}


ARDL Error Correction Regression

Dependent Variable: D(LNBM)

Selected Model: ARDL $(1,0,1)$

Case 3: Unrestricted Constant and No Trend

Date: 04/01/19 Time: 15:37

Sample: 144

Included observations: 41

\begin{tabular}{lrlrr}
\hline \hline \multicolumn{5}{c}{ ECM Regression } \\
\multicolumn{5}{c}{ Case 3: Unrestricted Constant and No Trend } \\
\multicolumn{1}{c}{ Variable } & Coefficient & Std. Error & t-Statistic & Prob. \\
\hline \hline C & -0.252025 & 0.087003 & -2.896753 & 0.0064 \\
D(LNINF) & 0.036154 & 0.012007 & 3.011025 & 0.0047 \\
CointEq(-1)* & -0.064565 & 0.013329 & -4.843926 & 0.0000 \\
\hline \hline & & & & \\
R-squared & 0.383907 & Mean dependent var & 0.168555 \\
Adjusted R-squared & 0.351481 & S.D. dependent var & 0.045095 \\
S.E. of regression & 0.036315 & Akaike info criterion & -3.722799 \\
Sum squared resid & 0.050114 & Schwarz criterion & -3.597416 \\
Log likelihood & 79.31739 & Hannan-Quinn criter. & -3.677142 \\
F-statistic & 11.83951 & Durbin-Watson stat & 2.051750 \\
Prob(F-statistic) & 0.000101 & & & \\
\hline \hline
\end{tabular}

* $\mathrm{p}$-value incompatible with t-Bounds distribution.

F-Bounds Test

Null Hypothesis: No levels relationship

\begin{tabular}{lcrrr}
\hline \hline Test Statistic & Value & Signif. & $\mathrm{I}(0)$ & $\mathrm{I}(1)$ \\
\hline \hline \multirow{2}{*}{ F-statistic } & 7.409564 & $10 \%$ & 3.17 & 4.14 \\
$\mathrm{k}$ & 2 & $5 \%$ & 3.79 & 4.85 \\
& & $2.5 \%$ & 4.41 & 5.52 \\
& & $1 \%$ & 5.15 & 6.36 \\
\hline \hline
\end{tabular}

t-Bounds Test

Null Hypothesis: No levels relationship

\begin{tabular}{lcrrr}
\hline \hline Test Statistic & Value & Signif. & $\mathrm{I}(0)$ & $\mathrm{I}(1)$ \\
\hline \hline \multirow{2}{*}{ t-statistic } & \multirow{2}{*}{-4.843926} & $10 \%$ & -2.57 & -3.21 \\
& & $5 \%$ & -2.86 & -3.53 \\
& & $2.5 \%$ & -3.13 & -3.8 \\
& $1 \%$ & -3.43 & -4.1 \\
\hline \hline
\end{tabular}

Full text of this article can be downloaded from www.craiaj.com and www.nepjol.info 
ARDL Long Run Form and Bounds Test

Dependent Variable: D(LNINF)

Selected Model: ARDL $(1,1,2)$

Case 3: Unrestricted Constant and No Trend

Date: 04/01/19 Time: 15:44

Sample: 144

Included observations : 40

\begin{tabular}{crrrr}
\hline \hline \multicolumn{5}{c}{ Conditional Error Correction Regression } \\
\hline \hline Variable & Coefficient & Std. Error & t-Statistic & Prob. \\
\hline \hline C & -0.185460 & 3.028849 & -0.061231 & 0.9515 \\
LNINF(-1)* & -1.024383 & 0.150666 & -6.799027 & 0.0000 \\
LNGDP(-1) & 0.412120 & 0.967054 & 0.426160 & 0.6728 \\
LNBM(-1) & -0.363346 & 0.738448 & -0.492040 & 0.6259 \\
D(LNGDP) & 1.979436 & 1.177240 & 1.681421 & 0.1021 \\
D(LNBM) & 3.553957 & 1.615801 & 2.199502 & 0.0350 \\
D(LNBM(-1)) & 3.706215 & 1.647539 & 2.249547 & 0.0313 \\
\hline \hline
\end{tabular}

* $\mathrm{p}$-value incompatible with t-Bounds distribution.

\begin{tabular}{ccccc}
\hline \hline \multicolumn{5}{c}{ Levels Equation } \\
Case 3: Unrestricted Constant and No Trend & \\
\hline \hline Variable & Coefficient & Std. Error & t-Statistic & Prob. \\
\hline \hline LNGDP & 0.402310 & 0.944017 & 0.426168 & 0.6728 \\
LNBM & -0.354698 & 0.720946 & -0.491989 & 0.6260 \\
\hline \hline EC $=$ LNINF - $\left(0.4023^{*}\right.$ LNGDP & $-0.3547^{*}$ LNBM $)$ & & \\
\hline \hline
\end{tabular}

F-Bounds Test

Null Hypothesis: No levels relations hip

\begin{tabular}{|c|c|c|c|c|}
\hline Test Statistic & Value & Signif. & $\mathrm{I}(0)$ & $\mathrm{I}(1)$ \\
\hline & & \multicolumn{3}{|c|}{ Asymptotic: $n=1000$} \\
\hline F-statistic & 15.78248 & $10 \%$ & 3.17 & 4.14 \\
\hline \multirow{3}{*}{ k } & 2 & $5 \%$ & 3.79 & 4.85 \\
\hline & & $2.5 \%$ & 4.41 & 5.52 \\
\hline & & $1 \%$ & 5.15 & 6.36 \\
\hline \multirow[t]{4}{*}{ Actual Sample Size } & 40 & \multicolumn{3}{|c|}{ Finite Sample: $n=40$} \\
\hline & & $10 \%$ & 3.373 & 4.377 \\
\hline & & $5 \%$ & 4.133 & 5.26 \\
\hline & & $1 \%$ & 5.893 & 7.337 \\
\hline
\end{tabular}

t-Bounds Test

Null Hypothesis: No levels relations hip

\begin{tabular}{lcrrr}
\hline \hline Test Statis tic & Value & Signif. & $\mathrm{I}(0)$ & $\mathrm{I}(1)$ \\
\hline \hline t-statistic & -6.799027 & $10 \%$ & -2.57 & -3.21 \\
& & $5 \%$ & -2.86 & -3.53 \\
& & $2.5 \%$ & -3.13 & -3.8 \\
& & $1 \%$ & -3.43 & -4.1 \\
\hline \hline
\end{tabular}

Full text of this article can be downloaded from www.craiaj.com and www.nepjol.info 
ARDL Error Correction Regression

Dependent Variable: D(LNINF)

Selected Model: ARDL(1, 1, 2)

Case 3: Unrestricted Constant and No Trend

Date: 04/01/19 Time: 15:45

Sample: 144

Included observations: 40

ECM Regression

Case 3: Unrestricted Constant and No Trend

\begin{tabular}{crlrl}
\hline \hline Variable & Coefficient & Std. Error & t-Statistic & Prob. \\
\hline \hline C & -0.185460 & 0.277266 & -0.668890 & 0.5082 \\
D(LNGDP) & 1.979436 & 1.055486 & 1.875379 & 0.0696 \\
D(LNBM) & 3.553957 & 1.525702 & 2.329391 & 0.0261 \\
D(LNBM(-1)) & 3.706215 & 1.586442 & 2.336180 & 0.0257 \\
CointEq(-1)* & -1.024383 & 0.144556 & -7.086394 & 0.0000 \\
\hline \hline R-squared & 0.626849 & Mean dependent var & 0.011608 \\
Adjusted R-squared & 0.584203 & S.D. dependent var & 0.575607 \\
S.E. of regression & 0.371165 & Akaike info criterion & 0.972128 \\
Sum squared resid & 4.821717 & Schwarzcriterion & 1.183238 \\
Log likelihood & -14.44255 & Hannan-Quinn criter. & 1.048458 \\
F-statistic & 14.69892 & Durbin-Watson stat & 1.961604 \\
Prob(F-statistic) & 0.000000 & & & \\
\hline \hline
\end{tabular}

* p-value incompatible with t-Bounds distribution.

\begin{tabular}{lcrrr}
\hline \hline Test Statistic & Value & Signif. & $\mathrm{I}(0)$ & $\mathrm{I}(1)$ \\
\hline \hline F-statistic & 15.78248 & $10 \%$ & 3.17 & 4.14 \\
$\mathrm{k}$ & 2 & $5 \%$ & 3.79 & 4.85 \\
& & $2.5 \%$ & 4.41 & 5.52 \\
& & $1 \%$ & 5.15 & 6.36 \\
\hline \hline
\end{tabular}

t-Bounds Test

Null Hypothesis: No levels relations hip

\begin{tabular}{lcrrr}
\hline Test Statistic & Value & Signif. & $\mathrm{I}(0)$ & $\mathrm{I}(1)$ \\
\hline \hline t-statistic & -7.086394 & $10 \%$ & -2.57 & -3.21 \\
& & $5 \%$ & -2.86 & -3.53 \\
& & $2.5 \%$ & -3.13 & -3.8 \\
& $1 \%$ & -3.43 & -4.1 \\
\hline \hline
\end{tabular}

Full text of this article can be downloaded from www.craiaj.com and www.nepjol.info 


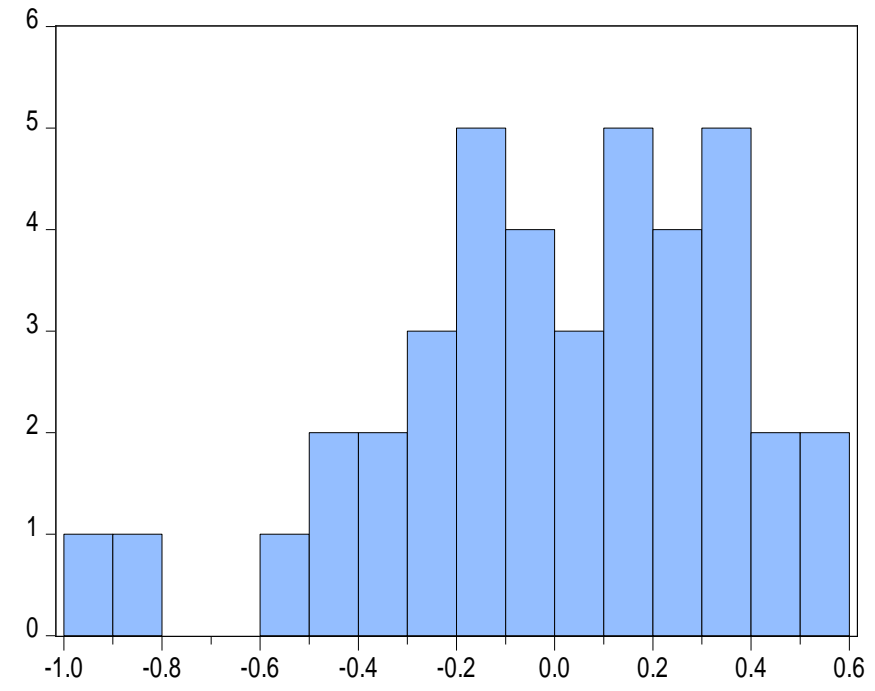

Series: Residuals

Sample 544

Observations 40

Mean $\quad-5.93 e-15$

Median $\quad 0.049780$

Maximum $\quad 0.538273$

Minimum $\quad-0.954444$

Std. Dev. $\quad 0.351616$

Skewness $\quad-0.683675$

Kurtosis $\quad 3.214733$

Jarque-Bera $\quad 3.192929$

Probability $\quad 0.202612$

Heteroskedasticity Test: ARCH

\begin{tabular}{llll}
\hline \hline & & & \\
F-statistic & 0.103483 & Prob. F(1,37) & 0.7495 \\
Obs*R-squared & 0.108772 & Prob. Chi-Square(1) & 0.7415 \\
\hline \hline
\end{tabular}

Test Equation:

Dependent Variable: RESID^2

Method: Least Squares

Date: 04/01/19 Time: 15:58

Sample (adjusted): 644

Included observations: 39 after adjustments

\begin{tabular}{lrlrr}
\hline \hline \multicolumn{1}{c}{ Variable } & Coefficient & Std. Error & t-Statistic & Prob. \\
\hline \multicolumn{1}{c}{ C } & 0.116952 & 0.035584 & 3.286614 & 0.0022 \\
\multicolumn{1}{c}{ RESID^2(-1) } & 0.052585 & 0.163465 & 0.321688 & 0.7495 \\
\hline \hline & 0.002789 & Mean dependent var & 0.123261 \\
R-squared & -0.024163 & S.D. dependent var & 0.183226 \\
Adjusted R-squared & 0.185427 & Akaike info criterion & -0.482393 \\
S.E. of regression & 1.272175 & Schwarz criterion & -0.397082 \\
Sum squared resid & 11.40666 & Hannan-Quinn criter. & -0.451784 \\
Log likelihood & 0.103483 & Durbin-Watson stat & 1.942926 \\
F-statistic & 0.749500 & & & \\
Prob(F-statistic) & & & & \\
\hline \hline
\end{tabular}

Full text of this article can be downloaded from www.craiaj.com and www.nepjol.info 
Pairwise Granger Causality Tests

Date: 04/01/19 Time: 15:39

Sample: 144

Lags: 2

\begin{tabular}{lccc}
\hline \hline Null Hypothesis: & Obs & F-Statistic & Prob. \\
\hline \hline LNGDP does not Granger Cause LNBM & \multirow{2}{*}{42} & 0.80554 & 0.4545 \\
LNBM does not Granger Cause LNGDP & & 5.00078 & 0.0120 \\
\hline \hline LNINF does not Granger Cause LNBM & \multirow{2}{*}{39} & 2.78447 & 0.0759 \\
LNBM does not Granger Cause LNINF & & 3.08654 & 0.0586 \\
\hline \hline LNINF does not Granger Cause LNGDP & \multirow{2}{*}{39} & 3.58063 & 0.0388 \\
LNGDP does not Granger Cause LNINF & & 0.87288 & 0.4269 \\
\hline \hline
\end{tabular}

Full text of this article can be downloaded from www.craiaj.com and www.nepjol.info 